\title{
Boron foliar application, branch girdling and plant growth regulators on yield and fruit quality of 'Garber' pear trees
}

\section{CLEVISON L. GIACOBBO ${ }^{1}$, LUCIANO PICOLOTTO ${ }^{2}$, MATEUS S. PASA ${ }^{3}$ and JOSÉ CARLOS FACHINELLO ${ }^{4}$}

\author{
${ }^{1}$ Departamento de Agronomia/PPGCTA, Universidade Federal da Fronteira Sul/UFFS, Campus \\ Chapecó, Rodovia SC 484, Km 02, Fronteira Sul, 89815-899 Chapecó, SC, Brazil \\ ${ }^{2}$ Departamento de Agronomia, Campus Curitibanos, Universidade Federal de Santa Catarina/ \\ UFSC, Rodovia Ulysses Gaboardi, Km 3, 89520-000 Curitibanos, SC, Brazil \\ ${ }^{3}$ Departamento de Fitotecnia, Empresa de Pesquisa Agropecuária e Extensão Rural de Santa Catarina/ \\ Epagri, Rua João Araújo Lima, 102, Jardim Caiçara, 88600-000 São Joaquim, SC, Brazil \\ ${ }^{4}$ Departamento de Fitotecnia, Universidade Federal de Pelotas/UFPel, Avenida \\ Eliseu Maciel, s/n, 96050-500 Capão Leão, RS, Brazil
}

Manuscript received on February 21, 2017; accepted for publication on December 20, 2017

\begin{abstract}
The aim of this study was to evaluate the influence of boron foliar application, branch girdling and plant growth regulators on the performance of pear trees cv. Garber. The experiment was arranged in a randomized block design with three replications. Treatments consisted of different boron rates $(220,440$,

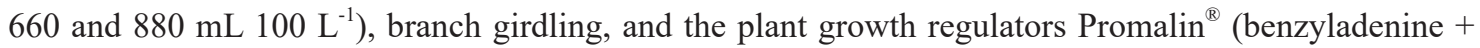

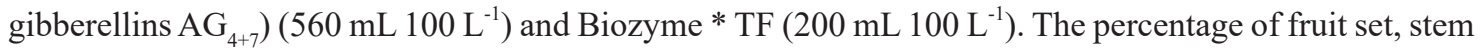
length, fruit length, fruit diameter, flesh firmness, soluble solids and yield were assessed. The greatest fruit set was observed with Promalin ${ }^{\circledR}$ in both years and also boron and Biozyme * TF in the second year. The use of Promalin ${ }^{\circledR}$ increased peduncle length, fruit height but negatively affected soluble solids. Yield was also increased by this plant growth regulator and boron. Concluding, Promalin ${ }^{\circledR}$ improves fruit set, yield, and fruit quality and boron positively influence yield.
\end{abstract}

Key words: Pyrus sp., fruiting, plant growth regulator, Promalin ${ }^{\circledR}$, nutrition.

\section{INTRODUCTION}

The production of fruit crops worldwide in 2012 was 636 millions of tons, where pears represented $3.7 \%$ of this amount. China has the largest pear production, representing $68 \%$ of the total produced in the world, while Brazil shows negligible production, i.e., only $0.09 \%$ (FAO, 2016). That is the reason pear is the most imported fruit in

Correspondence to: Clevison Luiz Giacobbo

E-mail: giacobbo@gmail.com
Brazil, representing an important opportunity to Brazilian growers (Pasa et al. 2012). This scenario results from several limiting factors, like the lack of definition of cultivars and rootstocks adapted to the potential regions and of suitable tree management practices, besides the lack of research to overcome these problems

According to Fioravanço (2007), the lack adaptation of the main high quality pear varities to the conditions of Southern Brazil, mainly regarding the requirement of chilling hours $\left(\mathrm{h} \leq \mathrm{a} 7,2^{\circ} \mathrm{C}\right)$, 
requires the use of chemical substances to induce better budbreak and flowering. These authors also say the climatic requirements, partially fulfilled in the main potential regions, is one of the main limiting factors for growing pears, because it difficults the use of high quality cultivars, besides favoring the production of low quality fruits.

The low fruit set is one of the main problems associated with pear growing in Southern Brazil, resulting in low yields. In the climatic conditions of this region, the lack of coincidence of blossom among the cultivars is common, resulting in low fruit set and yield. In such conditions, the fruit set of pears may be improved by the use of plant growth regulators (Hawerroth et al. 2011). These substances may increase bud fertility (Albuquerque et al. 2008), being a potential tool to increase yield (Dussi et al. 2011, Petri et al. 2011). According to Dussi et al. (2011), combinations like cytokinins and gibberellins (Promalin, $\mathrm{GA}_{4 / 7}+\mathrm{BA}$ ) may improve pear flowering and fruit size. Plant growth regulators could be sprayed either alone or in combination.

Pear fruit set may also be improved by cultural practices like branch girdling, either alone or in combination with other practices. Santos et al. (2014) and Pereira et al. (2011) observed that girdling increased the amount of starch and total soluble solids of 'Tahiti' limes. Giacobbo et al. (2012) found that the use of girdling associated with boron increases the fruit set of 'Navelina' oranges. This practice has the potential to increase fruit set (Pereira et al. 2011) and yield of pear trees, besides reducing shoot growth (Iuchi et al. 2008). Silva et al. (2010), observed that shoot girdling of 1-year-old shoots during the winter increased fruit set of 'Garber' pears. On the other hand, the effect of girdling seems to be dependent on the type of shoot, since girdling of spurs reduced fruit set. Other practices, such as the application of boron may increase pear fruit set.
The main effects of foliar application of boron in pears were increased concentration in the buds, anther weight, and pollen weight, resulting in positive effects on pollen quantity and quality (Lee et al. 2009). According to Acuña and Molina (2007), even though boron essentiality has been demonstrated so far, its biochemical function is not yet well understood. Recent reviews suggest this element is involved in three major processes, including the preservation of cell wall structure, maintenance of membrane cofactor functions and metabolic activities. Boron fertilization has shown to increase yield and fruit color in apples (Wojcik et al. 2008). However, the effect of boron fertilization was not observed in 'Imperial Gala' and 'Fuji Suprema' apple, suggesting that other factor might be involved (Sá et al. 2014).

The objective of this study was to evaluate the influence of boron foliar application, branch girdling and plant growth regulators on yield and fruit quality of 'Garber' pear trees.

\section{MATERIALS AND METHODS}

The study was conducted at the experimental field of Federal University of Pelotas located in the municipality of Capão do Leão, in the State of Rio Grande do Sul, Brazil (31'52'00”'S, 52²1'24”W, at $48 \mathrm{~m}$ of altitude), during the growing seasons of 2004/05 and 2005/06. According to the classification of Köppen, the climate of the region is classified as $\mathrm{C}$, subtype $\mathrm{Cfa}$ (Subtropical climate), with cold and humid winter and mild and dry summer. The monthly average temperatures (minimum and maximum) and rainfall, are shown in Table I. Orchard fertilization was performed according to recommendations to pear crop and was not irrigated.

Plant material consisted of 15 years old of the European cultivar Garber, grafted on the clonal rootstock of Pyrus calleryana. Trees were trained in a central leader system, spaced $8 \mathrm{~m}$ between 
TABLE I

Weather conditions of the experimental feld located at the municipality of Capão do Leão, in the State of Rio Grande do Sul, Brazil ${ }^{(1)}$.

\begin{tabular}{|c|c|c|c|c|c|c|c|}
\hline \multirow{3}{*}{ Month } & \multicolumn{4}{|c|}{ Monthly average temperature $\left({ }^{\circ} \mathrm{C}\right)$} & \multirow{2}{*}{\multicolumn{3}{|c|}{$\begin{array}{l}\text { Monthly rainfall } \\
\qquad(\mathrm{mm})\end{array}$}} \\
\hline & \multicolumn{2}{|c|}{ Minimum } & \multicolumn{2}{|c|}{ Maximum } & & & \\
\hline & 2004 & 2005 & 2004 & 2005 & 2004 & 2005 & 2006 \\
\hline January & 19.4 & 19.0 & 27.8 & 30.4 & 67.2 & 70.4 & 122.8 \\
\hline February & 18.3 & 19.1 & 28.1 & 27.9 & 71.0 & 96.4 & 82.8 \\
\hline March & 17.7 & 17.4 & 27.2 & 28.2 & 47.2 & 71.0 & 135.6 \\
\hline April & 16.3 & 13.7 & 25.5 & 23.8 & 132.0 & 166.6 & \\
\hline May & 11.9 & 12.4 & 18.7 & 21.3 & 491.4 & 99.0 & \\
\hline June & 10.8 & 13.4 & 19.3 & 21.6 & 57.7 & 28.2 & \\
\hline July & 8.5 & 8.9 & 17.5 & 19.4 & 95.4 & 42.2 & \\
\hline August & 10.3 & 11.1 & 19.6 & 20.7 & 94.6 & 94.8 & \\
\hline September & 12.3 & 11.3 & 21.2 & 18.2 & 90.3 & 241.6 & \\
\hline October & 12.2 & 13.2 & 22.3 & 21.5 & 112.0 & 93.3 & \\
\hline November & 15.6 & 15.5 & 23.7 & 27.3 & 91.5 & 23.7 & \\
\hline December & 17.3 & 16.1 & 26.7 & 27.0 & 28.6 & 45.6 & \\
\hline
\end{tabular}

(1) Data obtained from the weather station located at the municipality of Pelotas (Estação Agroclimatológica de Pelotas, 2017), in the State of Rio Grande do Sul, Brazil.

rows and $6 \mathrm{~m}$ within the row $\left(208\right.$ trees ha $\left.{ }^{-1}\right)$. The treatments consisted of: 1) Control; 2) Boron; 2.20 $\mathrm{mL} \mathrm{L}^{-1} \mathrm{H}_{2} \mathrm{O}$; 3) Boron $4.40 \mathrm{~mL} \mathrm{~L}^{-1} \mathrm{H}_{2} \mathrm{O}$; 4) Boron $6.60 \mathrm{~mL} \mathrm{~L}^{-1} \mathrm{H}_{2} \mathrm{O}$; 5) Boron $8.80 \mathrm{~mL} \mathrm{~L}^{-1} \mathrm{H}_{2} \mathrm{O}$; 6) Branch Girdling (BG); 7) Promalin ${ }^{\circledR}$ (benzyladenine + gibberellins $\left.\mathrm{AG}_{4}+\mathrm{AG}_{7}\right) 5.60 \mathrm{~mL} \mathrm{~L}^{-1} \mathrm{H}_{2} \mathrm{O}$ and; 8) Biozyme*TF (Nitrogen: 1.5; Potassium: 5.0; Boron: 0.08; Iron: 0.4; Manganese: 1.0; Zinc: 2.0; Sulfur: 1.0) $2.00 \mathrm{~mL} \mathrm{~L}^{-1} \mathrm{H}_{2} \mathrm{O}$ de (used only in the 2005 growing season). Boron concentrations were defined by the authors based on recommendations for apple trees. The solutions were applied to runoff with a backpack sprayer.

The fruit set (\%), fruit stem length $(\mathrm{cm})$, fruit length $(\mathrm{mm})$, fruit diameter $(\mathrm{mm})$, flesh firmness $(\mathrm{Lb})$, soluble solids ( ${ }^{\circ}$ Brix) and yield (ton $\mathrm{ha}^{-1}$ ) were evaluated. The total number of flower buds was counted at budburst, in four evenly selected branches. Branch girdling was performed at the end of previous season before leaf fall. Boron was sprayed at budburst (stage 3) and white bud (stage 5), while Promalin ${ }^{\circledR}$ was sprayed at green cluster (stage 4), and white bud (stage 5). After 10 and 40 days from the last application, the number of opened flowers and the number of fruits (15-20 $\mathrm{mm}$ ) were counted, respectively. The accumulation of chilling hours between the months of May and September was $441 \mathrm{~h}$ and $304 \mathrm{~h}$, in 2004 and 2005, respectively.

The experiment was arranged in a randomized block design, with three single-tree replications. The data were analyzed for statistical significance using the F test. Duncan's test $(P \leq 0.05)$ was performed to compare treatments when $\mathrm{F}$ test showed significant differences among means, using the statistical software WinStat (Machado and Conceição 2005). Fruit set data were transformed to $\arcsin (\mathrm{x} / 100)^{1 / 2}$ in order to meet the assumptions for analysis of variance.

\section{RESULTS AND DISCUSSION}

In the first season Promalin ${ }^{\circledR}$ increased fruit set relative to the other treatments, not differing of the treatments Boron 440 and $880 \mathrm{~mL} 100 \mathrm{~L}^{-1}$. This effect was probably because of the gibberellins 
present in Promalin ${ }^{\circledR}$ formulation, which usually induce greater fruit set even when pollination is deficient, while boron seems to have greater effect when used in greater concentrations. Similar results were observed in the 2005/06 growing season, and the inclusion of Biozyme*TF did not differ of Promalin $^{\circledR}$ (Figure 1a), indicating the effectiveness of these two substances to increase pear fruit set. Regardless the treatment, there was a clear decrease on fruit set from the first to the second growing season, possibly due to the greater amount of precipitation during flowering (September 2005), which may have impaired pollination and (Table I).

Fauate et al. (2007), emphasize Promalin ${ }^{\circledR}$ $(6-\mathrm{BA}+\mathrm{GA} 4+7)$ as an important substance to cell division and elongation. In the present study, the highest fruit set was $5.97 \%$, observed with Promalin $^{\circledR}$, similarly as found by Silva et al. (2010), in a study with the same cultivar and rate of this plant growth regulator. Similar value was observed in 'Garber' pears by Bianchi et al. (2000), using 20 $\mathrm{mg} \mathrm{L}^{-1}$ of gibberellic acid. Even though Promalin ${ }^{\circledR}$ stood out in our study, the results were much lower than the fruit set of $90.9 \%$ observed by these authors with $30 \mathrm{mg} \mathrm{L}^{-1}$ of thidiazuron (TDZ). It is important to emphasize that fruit set is influenced by different factors, like the shoot position in the tree. This effect was observed by Silva et al. (2010), which observed that the application of Promalin ${ }^{\circledR}$ in shoots at each of the four cardinal directions resulted in fruit set varying from $6 \%$ to $30.25 \%$. Giacobbo et al. (2012) also observed differences in fruit set of oranges among the four cardinal directions and the use of Promalin ${ }^{\circledR}$ associated with branch girdling. According to Nava et al. (2009b), fruit set may also be influenced by tree fertility, rootstocks, environment, stigma receptivity, pollen tube growth ability, nutritional status, and reserve accumulation in the trees. In fact, we observed greater fruit set in the 2004/05 growing season, which may be partially attributed to the effect of environment. In this season, there was a greater accumulation of chilling hours, as well as much lower precipitation $(93.2 \mathrm{~mm})$ during flowering than in 2005/06 (241.2 $\mathrm{mm})$, which probably hindered bee activity, and consequently pollination and fruit set.

The absence of differences among Biozyme*TF and Promalin ${ }^{\circledR}$ was also observed by Silva et al. (2010) in 1-year-old flowering shoots and bourse shoots. However, this similarity was not found in 1-year-old vegetative shoots. In this case, Biozyme*TF stood out with a fruit set of $25.33 \%$. These authors also observed differences between both plant growth regulators among shoots at the four cardinal directions. The results observed in our study and by Silva et al. (2010) are important and might be used to identify some of the factors related to fruit set in pears.

On the other hand, it has been suggested that boron is related to pollen quality, increasing its germination and weight, besides stimulating the formation of pollen tube with increasing rates of boron (25 to $200 \mathrm{mg} \mathrm{L}^{-1}$ ) (Lee et al. 2009). These authors emphasize that high rates of boron (400 and $500 \mathrm{mg} \mathrm{L}^{-1}$ ) may inhibit pollen tube formation, and this effect might have occurred with the higher rates of boron used in our study. Pollen germination may also be influenced by boron, being increased with acid boric rates up to $100 \mathrm{mg} \mathrm{L}^{-1}$, but reducing in higher rates (Lee et al. 2009). The optimum concentration of boric acid for pollen germination also depends on other factors, such as genotype, as observed Reis et al. (2011), in a study with banana trees.

The average stem length was greater with Promalin $^{\circledR}$ (Figure 1b). Similar results were observed by Dabul and Ayub (2005), which found that its use resulted in greater stem length of apples. These results suggest that the mode of action of gibberellins and cytokinins is possibly related to cell division and elongation, as described by Fioravanço et al. (2010). The application of Promalin ${ }^{\circledR}$ promoted cell elongation in 'Imperial 
Gala'apples (Leite et al. 2006). According to Westfall et al. (2013), cytokinins are responsible for cell division while gibberellins are related to cell elongation and growth. The greater stem length is an important factor considering pest and disease control, because a greater number of fruits per inflorescence is supported, reducing the direct contact among them, which may difficult spraying deposition and result in fruit deformation.

Considering the parameter fruit length, the application of gibberellins usually promote cellular elongation, and consequently it may affect fruit elongation as well. In our study, significant differences were found only in the 2005/06 growing season, where fruits treated with Promalin ${ }^{\circledR}$ were more elongated, but differing only of boron $440 \mathrm{~mL}$ $100 \mathrm{~L}^{-1}$ (Figure 1c). This plant growth regulator also increased fruit length of persimmon fruits cv. Fuyu (Fauate et al. 2007) and apple cv. Fuji (Yildirim et al. 2014), and 'Imperial Gala' (Leite et al. 2006). However, we have observed that Promalin ${ }^{\circledR}$ are dependent on the growing season, suggesting that other factors may be involved. Giovanaz et al. (2014) emphasize application timing, Fauate et al. (2007) the dose, and Westfall et al. (2013) the influence of environment. According to Fauate et al. (2007), the application of Promalin ${ }^{\circledR}$ does not compromise fruit quality and significantly increase fruit size. Its stimulus to fruit growth is probably because this plant growth regulator is related to cell division and elongation, as described by Fioravanço et al. (2010). The greater fruit elongation may also be related to an inner characteristic of 'Garber', that is prone to set fruits by parthenocarpy when pollination is deficient. These fruits are often misshapen.

Flesh firmness and fruit diameter did not differ among treatments (data not shown). However, in the 2005/06 season, significant differences were observed for soluble solids (SS), where the treatment boron $660 \mathrm{~mL} 100 \mathrm{~L}^{-1}$ stood out, but differing only of Promalin ${ }^{\circledR}$ (Figure 1d). This similarity among treatments may indicate a uniform ripening and that the increase in boron rates may maintain fruit quality. Asgharzade et al. (2012) observed an increase of $9.18 \%$ in ${ }^{\circ}$ Brix of apples compared to control, in response to boric acid. In most species, soluble solids are not affected by the use of Promalin ${ }^{\circledR}$, as observed in 'Jubileu' peach (Giovanaz et al. 2014), 'Fuyu' persimmon (Fauate et al. 2007) and 'Gala' apple (Dabul and Ayub 2005). It is believed that the effects of Promalin ${ }^{\circledR}$ are mainly related to fruit growth (Fauate et al. 2007). According to Westfall et al. (2013), fruit growth is closer related to the hormone gibberellin and senescence delaying with cytokinin. In the present study, mainly in the $2005 / 06$ season, the use of Promalin ${ }^{\circledR}$ probably raised the levels of these hormones, thus delaying ripening and increasing SS. Application timing may also influence SS accumulation (Fioravanço et al. 2010). According these authors, application at full bloom induces higher SS accumulation, rather than application after petal fall.

Regarding the parameter yield, the treatment with Promalin ${ }^{\circledR}$ was superior to boron 880 and $220 \mathrm{~mL} 100 \mathrm{~L}^{-1}$, in the $2004 / 05$ growing season. However, in 2005/06, the opposite was observed, where Promalin ${ }^{\circledR}$ was among the treatments with lower yields, while the treatment with boron $880 \mathrm{~mL}$ $100 \mathrm{~L}^{-1}$ showed the greatest yield, not differing only of Biozyme*TF (Figure 1e). These results suggest that yield is influenced by the specific conditions of each growing season. According to Dussi (2011), the efficiency of plant growth regulators in pear is influenced by several factors, like cultivar, tree vigor, yield, climatic conditions (before, during and after application), application method (water volume, surfactant, etc.). The application timing is one of the most important factors to the efficiency in increasing production per tree (Giovanaz et al. 2014). The connection of gibberellins with flower development is possible directly related with yield (Westfall et al. 2013). 

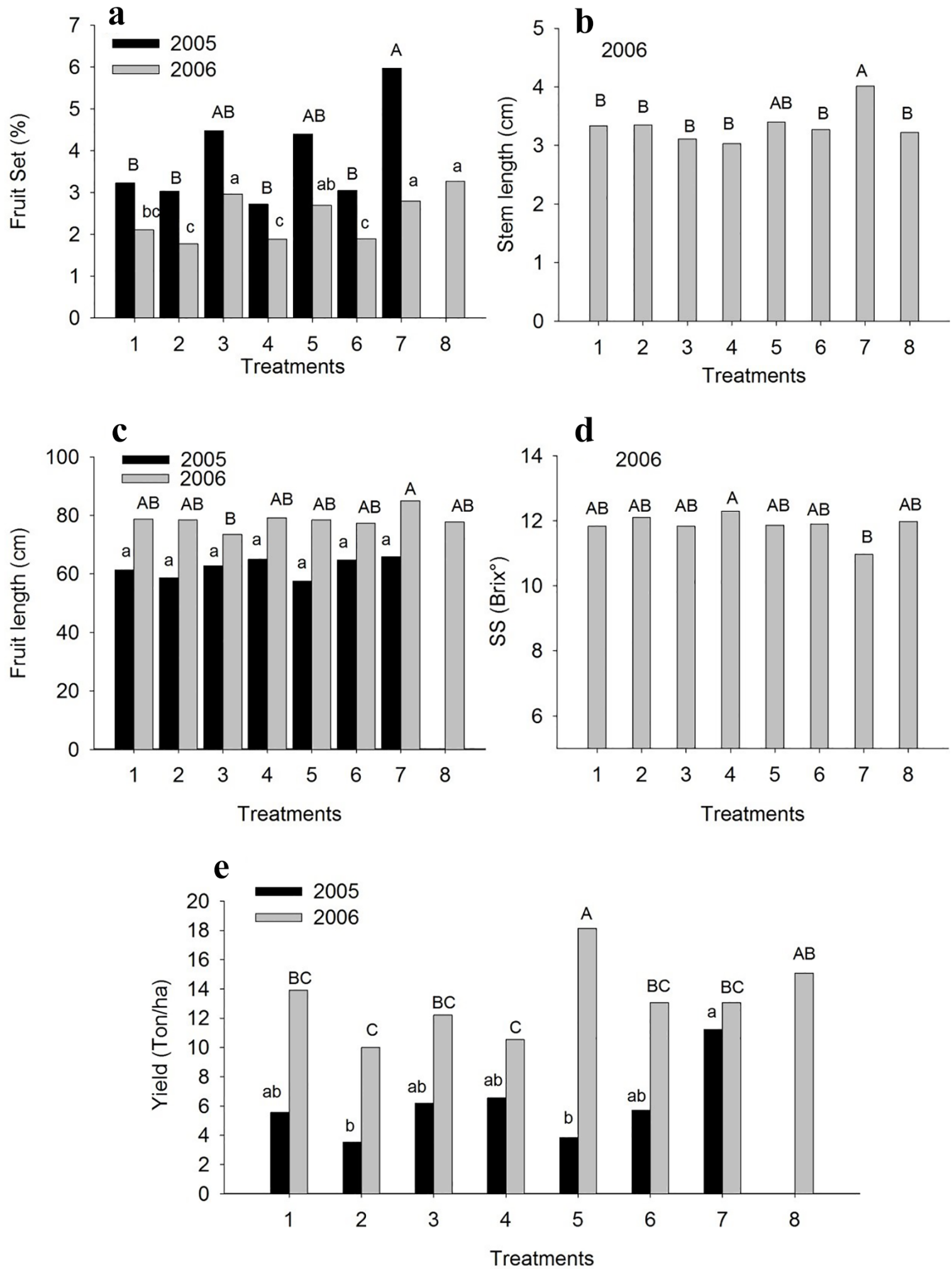

Figure 1 - Effect of foliar applied boron at different concentrations and plant growth regulators on fruit set (a), average stem length (b), fruit length (c), soluble solids (SS) (d) and yield (e) of 'Garber' pear trees, in the growing seasons of 2004/05 and 2005/06. 
Nava et al. (2009a) describe the boron as an element that may be related to yield. It is generally found in greater concentration in flowers, suggesting its relationship with the productive pattern (Spinardi and Bassi 2012). According to Maia et al. (2010), fruit set is connected with the amount of reserves, and may be reduced in trees showing alternate bearing. The higher amount of fruits in an "on" year might result in less nutrients available for the development of fruiting structures, thus impairing the production the next season ("off year"). This alternate bearing seems to have occurred in our study, since the treatments that showed the greatest yield in the first season, reduced in the second. The higher yield in the 2005/06 season with boron $880 \mathrm{~mL} 100 \mathrm{~L}^{-1}$, suggests that the adequate availability of boron is important and improves the accumulation of reserves in the tree.

Overall, in the first growing season (2004/05) fruit set and yield were greater with Promalin ${ }^{\circledR}$, possibly because the inner levels of $B$ in the trees were still low. However, considering that the treatments were sprayed to the same trees in 2005/06, the treatment with Promalin ${ }^{\circledR}$ showed intermediate results, and the highest rate of $\mathrm{B}$ showed the greatest fruit set and yield. Possibly, these results are due the cumulative effect of $\mathrm{B}$, since it was applied consecutively the two growing seasons.

\section{CONCLUSIONS}

Promalin ${ }^{\circledR}$ improves fruit set and stem length, but reduces total soluble solids of 'Garber' pear trees. Yield may be positively influenced by the use of Promalin $^{\circledR}$ and boron.

\section{ACKNOWLEDGMENTS}

The Coordenação de Aperfeiçoamento de Pessoal de Nível Superior (CAPES) and Conselho Nacional de Desenvolvimento Científico e Tecnológico $(\mathrm{CNPq})$ for grant support and to the researcher Carlos Reisser Júnior, from Embrapa Clima Temperado, for kindly providing the data of chilling accumulation.

\section{REFERENCES}

ACUÑA ADCM AND MOLINA PEC. 2007. Desempeño funcional del boro en las plantas. Rev Cient UDO Agr $7(1): 1-14$.

ALBUQUERQUE T, MOUCO MD AND ALBUQUERQUE AAD. 2008. Reguladores de crescimento vegetal na concentração de macronutrientes em videira Itália. Bragantia 67(3): 553-561.

ASGHARZADE A, ALI VALIZADE G AND BABAEIAN M. 2012. Investigating the effect of boron spray on yield nutrient content, texture and brix index of apple (Sheikh Amir Variety) in Shirvan region. AJMR 6(11): 2682-2685.

BIANCHI VJ, SILVEIRA CAP, FARIA JLC, FACHINELLO JC AND SILVA JB. 2000. Aumento da frutificação efetiva em pereiras cultivar garber com uso de $\mathrm{AG}_{3}$ e TDZ. Rev Bras de Agrosc 6(3): 191-193.

DABUL ANG AND AYUB RA. 2005. Efeito da aplicação de Promalin ${ }^{\circledR}$ em frutos de maçã (Malus domestica) cv. Gala. Rev Ceres 52: 351-356.

DUSSI MC. 2011. Sustainable use of plant bioregulators in pear production. ActaHort 909: 353-368.

ESTAÇÃO AGROCLIMATOLÓGICA DE PELOTAS. 2015. Agroclimatológico. Capão do Leão. Disponível em: $<$ http://www.cpact.embrapa.br/agromet/estacao/boletim. php> Acesso em 02 de agosto de 2017.

FAO. 2016. FAOSTAT data. Disponível em $<$ http://faostat.fao. org/DesktopDefault.aspx?PageID=567\&lang=es\#ancor $>$. Acesso em 22 de outubro de 2016.

FAUATE A, FAUATE M, AYUB RA AND MALGARIM MB. 2007. Aplicação de $\mathrm{GA}_{4,7}+\mathrm{BA}$ (Promalina) afetando o crescimento, desenvolvimento e qualidade do caqui (Diospyros kaki L.) cv. Fuyu. Ceres 54(313): 226-230.

FIORAVANÇO JC. 2007. A cultura da pereira no Brasil: situação econômica e entraves para o seu crescimento. Informações Econômicas 37(3): 52-59.

FIORAVANÇO JC, DE ALMEIDA GK AND SILVA VC. 2010. Efeito da Promalina ${ }^{\circledR}\left(\mathrm{GA}_{4+7}+6 \mathrm{BA}\right)$ na produção e desenvolvimento dos frutos da macieira cv. Royal Gala. Rev Ciênc Agrovet 9(2): 143-149.

GIACOBBO CL, RIGHI OS, ROSSAROLLA MD, LAGO C AND FISCHER DLO. 2012. Fruit set and quality of 'NAVELINA' orange under different treatments. ActaHort 928: 297-302.

GIOVANAZ MA, FACHINELLO JC, GOULART C, RADÜNZ AL, AMARAL PA AND WEBER D. 2014. Produção e qualidade de pêssegos, cv. Jubileu, com uso de fitorreguladores. Ceres 61(4): 552-557. 
HAWERROTH FJ, HERTER FG, FACHINELLO JC, PETRI JL, PREZOTTO ME, HAAS LB AND PRETTO A. 2011. Aumento da produção de pereira asiática pelo uso de fitorreguladores. Cienc Rural 41(10): 1750-1754.

IUCHI T, IUCHI VL, HERTER FG AND BRIGHENTI E. 2008. Anelamento e paclobutrazol na produção e absorção de nutrientes em pereira (Pyrus communis 1.) cultivar packham's triumph. Rev Bras Frutic 30(4): 857-861.

LEE SH, KIM WS AND HAN TH. 2009. Effects of postharvest foliar boron and calcium applications on subsequent season's pollen germination and pollen tube growth of pear (Pyrus pyrifolia). Sci Hortic 122: 77-82.

LEITE GB, PETRI JL AND BASSO C. 2006. Promalin effect on 'Imperial Gala' and 'Fuji' apples trees fructification. Acta Horticulturae 727: 269-278.

MACHADO AA AND CONCEIÇÃO AR. 2005. WinStat Sistema de Análise Estatística para Windows. Versão Beta. Universidade Federal de Pelotas.

MAIA E, SIQUEIRA DL AND CECON PR. 2010. Produção, florescimento e frutificação de tangerineira 'Poncã' submetida à aplicação de ácido giberélico. Cienc Rural 40(3): 507-512.

NAVA GA, DALMAGO GA, BERGAMASCHI H AND MARODIN GAB. 2009a. Fenologia e produção de pessegueiros 'granada' com aplicação de cianamida hidrogenada e boro. Rev Bras Frutic 31(2): 297-304.

NAVA GA, MARODIN GAB AND SANTOS RP. 2009 b. Reprodução do pessegueiro: efeito genético, ambiental e de manejo das plantas. Rev Bras Frutic 31(4): 1218-1233.

PASA MS, FACHINELLO JC, SCHMITZ JD, SOUZA ALK AND DE-FRANCESCHI E. 2012. Desenvolvimento, produtividade e qualidade de peras sobre porta enxertos de marmeleiro e Pyrus calleryana. Rev Bras Frutic 34(3): 873-880

PEREIRA CS, SIQUEIRA DLD, SALOMÃO LCC, CECON PR AND SANTOS DD. 2011. Teores de carboidratos nas folhas e produção de limeiras ácida 'tahiti' aneladas e tratadas com ácido giberélico. Rev Bras Frutic 33(3): 706-712.

PETRI JL, LEITE GB, COUTO M AND FRANCESCATTO P. 2011. Avanços na cultura da macieira no Brasil. Rev Bras Frutic 33(3): 48-56.

REIS RVD, LINO LDSM, SILVA SDO, AMORIM EP, LEDO CADS AND VIANA AP. 2011. Viabilidade in vitro de grãos de pólen de bananeira sob diferentes concentrações de ácido bórico e sacarose. Ciênc Agrotec 35(3): 547-553.

SÁ AAD, ERNANI PR, NAVA G, AMARANTE CVTD AND PEREIRA AJ. 2014. Influência de formas de aplicação de boro na qualidade e no rendimento de maçãs (Malus domestica). Rev Bras Frutic 36(2): 487- 494.

SANTOS DD, SIQUEIRA DLD, SALOMÃO LCC, CECON PR, OLIVEIRA GP, MACHADO DLM AND ZUCOLOTO M. 2014. Teores de carboidratos e fluorescência da clorofila a em folhas de limeiras ácidas 'Tahiti' submetidas ao anelamento e incisão anelar de ramos. Cienc Rural 44(10): 1725-1731.

SILVA JB, GAZOLLA-NETO A, PAZZIN D, FACHINELLO JC AND GIACOBBO CL. 2010. Fruit set of pear fruits cultivar Garber in the different fruiting organs regarding to the quadrant, pruning, girdling, bending and chemical treatments. ActaHort 872: 289-294.

SPINARDI A AND BASSI D. 2012. Olive fertility as affected by crosspollination and boron. Sci World J 2012(2): 1-8.

WESTFALL CS, MUEHLER AM AND JEZ JM. 2013. Enzyme Action in the Regulation of plant hormone responses. J Biol Chem 288(27): 19304-19311.

WOJCIK P, WOJCIK M AND KLAMKOWSKI K. 2008. Response of apple trees to boron fertilization under conditions of low soil boron availability. Sci Hortic 116: 58-64.

YILDIRIM FA, KEPENEK G, ŞAN B, YILDIRIM AN AND KAÇAL E. 2014. Effects Of $\mathrm{Ba}+\mathrm{Ga}_{4+7}$ Treatments On Fruit Quality In 'Fuji' Apple Variety. Turk J Agric For 2: 1387-1390. 